\title{
Pope, Johnson and Swift: A Comparison of their Poetic Styles and Views on Human Nature
}

\author{
Liqun Feng \\ Boda College of Jilin Normal University, Siping City, Jilin Province, China \\ Email: fengliqun@aliyun.com
}

Received: $11 / 04 / 2020$

Accepted: 14/06/2020

Published: 01/07/2020

Volume: 1 Issue: 2

How to cite this paper: Feng, L. (2020). Pope, Johnson and Swift: A Comparison of their Poetic Styles and Views on Human Nature. Journal of Critical Studies in Language and Literature, 1(2), 37- 43

DOI: https://doi.org/10.46809/jcsll.v1i2.56

URL: https://jcsll.gta.org.uk/index.php/JCSLL/article/view/56/36

Copyright (C) 2020 by author(s) and Global Talent Academy Ltd. This work is licensed under the Creative Commons Attribution International License (CC BY 4.0).

http://creativecommons.org/licenses/by/4.0/

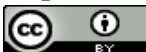

\begin{abstract}
This paper aims to compare the poetic styles and views on human nature of three literary giants in English literature, namely, Alexander Pope, Jonathan Swift and Samuel Johnson. As the three men of letters almost lived in the same age and they were all fond of writing on human nature, it will be very interesting to compare their respective styles and views on this issue. Since no previous studies have been found on this topic, this paper will be of great significance in exploring how their individual style and thinking vary from one another. Through close textual analysis of their representative poetic works, including An Essay on Man by Pope, The Vanity of Human Wishes by Johnson, and finally Verses on the Death of Dr. Swift, D.S.P.D. by Swift, this paper discovers the extent to which the three great authors differ from one another in their poetic styles and views on human nature. From Alexander Pope to Samuel Johnson and then down to Jonathan Swift, their respective poetic styles drop in formality and start to be increasingly less serious. Their views on human nature, accordingly, become increasingly hopeless and bleak. For Alexander Pope, self-love and reason are the central traits in human nature; to live a righteous life man has to use reason to counterbalance his self-love. For Samuel John, it is vanity that motivates all human actions; to resolve all the unhappiness in human life, however, man must use reason. Therefore, both poets emphasize reason as a combating force against all the ego-centrism inherent in human nature. As for Jonathan Swift, he even did not believe human beings are capable of reason; what he perceives in human nature is mere selfishness. This means that Pope and John are still serious about human nature and believe all the evilness in human nature can be mended or bettered, while Jonathan Swift starts to jeer at it, which signifies his complete loss of faith in human nature. Although they all believe egocentrism to be intrinsic in human nature, we can conclude that Jonathan Swift, among the three, possesses the bleakest view of human nature.
\end{abstract}

Keywords: Comparison, Poetic Style, Human Nature, Ego-Centrism

\section{Introduction}

Alexander Pope (1688-1744) is considered as one of the greatest English poets as well as representative poet of the eighteen century. He is best noted for The Rape of the Lock, The Dunciad, An Essay on Criticism, An Essay on Man and translation of Homer. An Essay on Man is a poem published by Alexander Pope in 1733-1734, the chief purpose of which is 
to "vindicate the ways of God to man" (1. 16). Voltaire praised this poem as "the most beautiful, the most useful, the most sublime didactic poem ever written in any language" (2003, p. 147).

Moreover, Samuel Johnson (1709-1784) is best known for his compilation of A Dictionary of the English Language. However, Johnson is also one of the greatest poets in English literature. The Vanity of Human Wishes: The Tenth Satire of Juvenal Imitated was penned by him in late 1748 and published in 1749. It aims to demonstrate "the complete inability of the world and of worldly life to offer genuine or permanent satisfaction" (Bate, 1977, p. 279). Howard D. Weinbrot regarded this poem as "one of the great poems in the English language" (1997, p.46).

Additionally, Jonathan Swift (1667-1745), as a great novelist and poet, was best remembered for his works such as A Tale of a Tub(1704), An Argument Against Abolishing Christianity (1712), Gulliver's Travels (1726), and A Modest Proposal (1729). Verses on the Death of Dr. Swift, D.S.P.D, which was written in 1731 and published in 1739, is one of his most impressive poems. With its 484 lines of satirical iambic tetrameter couplets, this poem powerfully conveys Jonathan Swift's view of human nature in a most memorable way.

As the three literary giants are all hailed for their satirical style and the three poems under their craftsmanship all touch upon the issue of human nature, it will be very interesting to explore how their individual style and view of human nature vary from one another. Moreover, as these poems were all composed in the first half of the 18th century, hopefully this comparison may shed light upon the conceptions of human nature during that particular age.

\section{Poetic Styles and Views on Human Nature}

The three poems mentioned above all concern the issue of human nature. As J. Tobin puts, "Pope was very much interested in human nature" (1945, p. 346). Pope was fond of talking about human nature and An Essay on Man clearly conveys Pope's views of this notion. In the first epistle of Pope's An Essay on Man, he begins with an urgent request:

Awake, my St. John! leave all meaner things

To low ambition, and the pride of kings.

Let us (since life can little more supply

Than just to look about us and to die)

Expatiate free o'er all this scene of man; (line 1-5)

Pope's voice, as we can imagine, is very high-pitched. He tries to awake his friend, not from sleeping, but from dwelling on "meaner things" and urges him to wonder "all this scene of man", which is life or humanity. Then he goes on to declare "A mighty maze!" (6). He feels astonished by this wonder of life and wants his friend to feel the same astonishment:

Laugh where we must, be candid where we can;

But vindicate the ways of God to man. (line 15-16)

His tone is somewhat like a prophet who humbly subjects himself to God. The world is a "A mighty maze", "but not without a plan" (6), which was designed by God. He, like a prophet, urges people to always follow God and not to betray Him. Similarly, Pope urges that we can laugh or be "candid", "but vindicate the ways of God to man". The word "candid" has its root in Latin, deriving from the verb candère, which means "be white, glow". And in ancient Rome, people who were standing for election wore white togas; they were thus called candidāti. Thus, the word generates a meaning that openly and frankly expresses political views. But the important thing is not this, but to prove the existence and powers of God to man. This opening clearly shows that Pope is a spokesman of God. Pope's style is grand as that of epics, yet it is also restraint with solemn religious undertone. However, this poem is without such seriousness of tone as can be found in Milton's Paradise Lost.

In the course of the poem, the words "pride", "reason", and "passion" occur frequently. They are key words towards understanding Pope's ideas of human nature:

II. Presumptuous man! the reason wouldst thou find,

Why formed so weak, so little, and so blind!

First, if thou canst, the harder reason guess,

Why formed no weaker, blinder, and no less! (line 35-38)

Pope labeled man as "Presumptuous", equivalent of "proud" and "vain". He seems to be asking, "Daring as you are, petty man, can you find the reason why you are 'formed so weak, so little, and so blind' and guess 'the harder reason' why you are 'formed no weaker, blinder, and no less'"? No, you cannot. You are so petty, so infinitesimal, impotent and limited. The word "pride" occurs very frequently in the first epistle, including "the proud steed" 61), "Man's pride" (65), and "In pride, in reasoning pride, our error lies; /All quit their sphere, and rush into the skies." (123-124). In Pope's view, man is daring and proud enough to transgress the path God arranged for him, instead of adhering to his proper position. We boast that we are 
the only animals who are capable of reasoning. Yet Pope asserts that it is reasoning that leads to our downfall. Pride is the very root of human errors, because it leads us to reason:

From pride, from pride, our very reasoning springs;

Account for moral, as for natural things:

Why charge we heaven in those, in these acquit?

In both, to reason right is to submit. (line 161-164)

We, being boastful of our ability to reason, try to set moral principles for us to behave and even venture to peep into the mystery of heaven by attributing it to natural phenomenon. But this is not the right reasoning. "In both [aspects], to reason right is to submit [oneself to God]". Pope's idea at the end of this epistle is most clearly conveyed:

And, spite of pride, in erring reason's spite,

One truth is clear, 'Whatever is, is right.' (line 293-294)

For man, to reason is to err, because he is too proud. Only one truth is clear: what is existing has been rightly arranged by God. Man should not venture to decipher the mystery of world and even of God. We can see Pope's humble posture before God in spite of his highly polished heroic couplets. Furthermore, the lofty style of this poem helps strengthen Pope's stance as God's eloquent spokesman. As Branciforte wrote, "'Whatever is, is right,' the loftiest, most condensed formula in the Essay on Man, still comes as a shock" (2019, p. 261). This poem is like an elevated sermon by a prophet or a priest. Pride is the principal vice of human nature according to Pope. In his second epistle, Pope also wrote about man's pride and pettiness, using poor Newton as an epitome, who, being the quintessence of human reason and intelligence, yet merely makes himself "an ape" (34) before "Superior beings" (31). Then he goes on to talk about two principles in human nature:

II. Two principles in human nature reign;

Self-love to urge, and reason, to restrain;

Nor this a good, nor that a bad we call,

Each works its end, to move or govern all

And to their proper operation still,

Ascribe all good; to their improper, ill. (line 53-58)

The two principles, self-love and reason, are polar drives in human nature. Self-love urges people into active motion, but reason restrains us from excess. These two drives are neutral, neither good nor bad, governing everybody. The way we use the two principles leads to either good or bad outcomes. Pope then talks about the balance and counter-balance of the two principles. But they have one common end, namely, pleasure:

Self-love and reason to one end aspire,

Pain their aversion, pleasure their desire;

But greedy that, its object would devour,

This taste the honey, and not wound the flower:

Pleasure, or wrong or rightly understood,

Our greatest evil, or our greatest good. (line 87-92)

Everyone desires pleasure and tries to avoid pain, which is what the two principles aspire to. This can lead to greediness, which is the desire to possess more. Therefore, the desire for pleasure, either wrongly or rightly understood and carried out, can cause "Our greatest evil, or our greatest good". To Pope, there is no such idea as "Man is good or evil by nature". He does not mean that we are inherently good or bad. The two principles, self-love and reason, are combined in human nature. Yet in reality, as we can infer, one often prevails over the other. Self-love has various modes, which are call "the passions". The passions are interchangeably used alongside with humours. The "ruling passion" is the same with the "vital humour". The passions cause vices and virtues alike. In the closing lines, once more Pope humbly submits man to God:

Ev'n mean self-love becomes, by force divine,

The scale to measure others' wants by thine.

See! and confess, one comfort still must rise,

'Tis this, though man's a fool, yet God is wise. (line 291-294)

God is almighty. He can even turn the mean self-love, which is extreme selfishness, to be an instrument for measuring other people's needs and desires by looking into one's own desire. Man is a fool and only God is wise. Man's foolishness lies in his pride to presume God's wisdom. 
In this poem, Pope lists pride as man's common vice, and self-love and reason as governing principles in human nature. Pride causes man to digress from the ways of God, while self-love and reason, the neutral drives, have pleasure as common end and pain as common foe. Passions as modes of self-love can breed either virtue or vice.

Samuel Johnson's poem resembles Pope's poem more than that of Swift's. Therefore, I will leave Swift the last one to discuss. Johnson's opening in The Vanity of Human Wishes is milder and calmer in tone than that of Pope's:

\author{
Let observation with extensive view \\ Survey mankind from China to Peru; \\ Remark each anxious toil, each eager strife, \\ And watch the busy scenes of crouded life, \\ Then say how hope and fear, desire and hate, \\ O'er spread with snares the clouded maze of fate, \\ Where wav'ring man, betray'd by vent'rous pride, \\ To tread the dreary paths without a guide, \\ As treach'rous phantoms in the mist delude, \\ Shuns fancied ills, or chases airy good. (p. 75-76)
}

Pope uses his urging voice and highly polished style to "vindicate the ways of God to man" in his opening to Essay on Man. In this opening, Samuel Johnson shares some common ideas with Pope. The whole mankind is forever in active motion, seeking and toiling. This reminds us of Pope's "self-love", which always urges the human body into motion. The "clouded maze of fate" echoes Pope's "mighty maze". We can infer that life or fate to both of them is a maze that human beings are only left to gaze and wonder. The "clouded maze of fate" or life is filled with "hope and fear, desire and hate", but where is love? Desire is not love. Pope has self-love, but Johnson has none. Pope thinks that man is weak and small; similarly Johnson comments man as "wav'ring", less firm and unable to walk steadily by himself. "Pride" in this poem is definitely a vice for Johnson to attack, as the title suggests. Man, "betray'd by vent'rous pride", errs by venturing "To tread the dreary paths without a guide". It is exactly what Pope says in his poem. Then he goes on to tell how mankind is tempted by fame and fortune, the two main modes of vanity. Great persons who were once preeminent could hardly manage to reach a happy ending. He entreats the "illustrious youth" (p79) to use virtue and reason as his guard and guide. That he mentions reason several times in this poem indicates his emphasis on reason in human life. Despite his didacticism, he has a gloomy view of human life:

That life protracted is protracted woe.

Time hovers o'er, impatient to destroy,

And shuts up all the passages of joy: (p. 82)

Pope, however, has nothing bleak in his outlook of life. His conception of human life depends on the balance of self-love and reason. According to Johnson, long life can only reward more pain. Why? It is because life is miserable or our human nature can merely cause misery to ourselves. Perhaps it is the latter. The vanity of our human nature always urges us to work and pursue. A protracted life is protracted toil, hope and disappointment. Thus it is protracted pain. This is why the vanity of our human nature merely causes pain to ourselves. "Man is, in other words, victimized, both within himself and, as it were, outside himself, by the imperfect world" (Aden, 1961, p. 298). Therefore, both man himself and the world he lives in contribute to his misery. We can note that compared with Pope, Johnson grew somber in his tone and view of human life:

For love, which scarce collective man can fill;

For patience sov'reign o'er transmuted ill;

For faith, that panting for a happier seat,

Thinks death kind Nature's signal of retreat:

These goods for man the laws of heav'n ordain,

These goods he grants, who grants the pow'r to gain;

With these celestial wisdom calms the mind,

And makes the happiness she does not find. (p. 85)

We have lost love in the opening of this poem, but now we regain it through God. Love, patience, and faith are three virtues that secure man the right ways to God. Nature is kind and death is no longer dreadful, but a "signal of retreat". The afterlife in heaven is happy and without sorrow. Similar to Pope, Johnson also regards God as the resolution to all pains and the way to the happiness granted by "celestial wisdom". For Johnson, "it is God, not man, who bestows upon the faithful Christians 'those goods' which make up happiness (Chapin, 1984, p. 75).

In this poem, Johnson surveys the people in this world and finds them all anxiously toiling and eagerly striving. Man is "wav'ring" but "stubborn". Only reason, as Johnson emphasizes, can correct them to the right course of life. Vanity, as manifested by wealth and fame, dominates man's mind from the past to the present, thus making life both painful and 
miserable. Vanity has two layers of meanings, one is being too interested in one's appearances or achievements while the other is emptiness or futility. In this poem, "vanity" has both meanings. Man is interested only in himself ("conceit" and "pride") or in his own business ("each anxious toil, each eager strife"); yet his toil and strife are all "in vain" at last. People all want to get benefits for the sake of their own interest. They are basically egocentric, though Johnson did not explicitly use such terms. Vanity is the manifestation of the ego-centrism of human nature, before which reason is impotent. Therefore, Johnson entreats people to follow the virtues of religion, which are the right ways to God and eternal bliss. In this aspect, he is very similar to Pope. Although the poem is also written in heroic couplets with an elevated and stately style, the tone is more controlled, lacking the kind of fervour in Pope's poem. Unlike Pope, he is like a teacher, teaching what is morally good and right.

Lastly, this paper analyzes Swift's Verses on the Death of Dr. Swift, which is dated earliest among the three but his style is so different from Pope's and Johnson's. This difference in style is reflected in his attitude towards human nature. Swift quotes Rochefoucauld's maxim as epigraph:

Dans l'adversité de nos meilleurs amis nous trouvons quelque chose, qui ne nous deplaist pas.

In the Adversity of our best Friends, we find something that doth not displease us. (Swift, 2015, p. 100)

This interesting opening is highly thought-provoking and thus very different from Pope's and Johnson's: why do we privately please at our best friends' misfortunes? We are very curious to know what he is going to talk about afterwards:

\author{
As Rochefoucault his Maxims drew \\ From Nature, I believe 'em true: \\ They argue no corrupted Mind \\ In him; the Fault is in Mankind. \\ This Maxim more than all the rest \\ Is thought too base for human Breast; \\ "In all Distresses of our Friends \\ We first consult our private Ends, \\ "While Nature kindly bent to ease us, \\ Points out some Circumstance to please us." (line 1-10)
}

In the opening, he believes Rochefoucauld's maxims are true, because they are drawn from nature. Perhaps the maxims are gloomy, yet this is not because Rochefoucauld is too cynical, but because "the Fault is in Mankind". This maxim is too base or gloomy for mankind to accept, but it is TRUE. We concern ourselves' interest first although our friends are in distresses, in which we even find some delights. Swift's view of human nature is the darkest and most extreme among the three. The didacticism in Pope and Swift is no longer apt to cure mankind.

The poems of Pope and Johnson are composed in iambic pentameter couplets, while their diction is formal and their tone controlled. They talk about "God", "Jove", "heaven" or "celestial wisdom" with considerable respect and seriousness. Yet this poem is composed in iambic tetrameter couplets. Shorter in length, quicker in rhythm and lighter in tone, we do not find any seriousness or didacticism in this poem. In Pope's poem, he rarely alludes to common names, except that "St. John" is an English name. Most often, the people he talks about are divine abstractions ("God", "Jove", "Providence", and "Order"), human beings in general ("Man", "Indian", and "Christian"), personifications ("Nature", "Pride", and "Vice") and ancient Greek or Roman figures ("Plato", "Borgia", "Catiline", "Ammon", and "Caesar"). In Johnson's poem, he talks about people of different professions of life ("king", "traveler", "senates", and "mayor"), personifications ("Fortune", "Misfortune", "Nature", "Reason", "Novelty", "Sloth", "Beauty", "Pride", and "Prudence"), occasionally ancient Greek or other historical figures ("Democritus", "Xerxes", and "Galileo"), and past and present English personages ("Wolsey", "Villiers", "Harley", "Wentworth", "Hyde", "Bodley", "Bacon", "Lydiat", "Swedish Charles", "Marlb'rough", "Swift", etc.). And he uses "thy" when addressing to the "illustrious youth". In Swift's poem, however, most of the names he alludes to are English figures or names well-known to the common people ("Ned", "Pope", Pox", "St. John", "Pultney", "Lady Suffolk", and "Bob"). And he often uses the first person pronoun "I" and the second person pronoun "you". Instead of the formal words such as can be found in the poems of Pope and Johnson, Jonathan Swift prefers to use the language of the common people. "He shows here an astonishing power - such as Wordsworth, for instance, never had - of taking the very ordinary common speech and tossing them with any awkward inversions into simple rhyming verse" (Davis, 1940, p. 246). He conveys his ideas on human nature in such simple language, yet with great power and vehement. We can note that the degree of formality drops from Pope to Johnson to Swift, the distance between the poet and the reader is drawn closer and closer. The tone shifts from impersonal to personal and intimate. The degree of gloominess in their attitudes towards human nature from Pope to Johnson to Swift aggravates. This change in style, especially in Swift, brings a sharp change in his attitudes towards human nature. The swiftness of rhythm and lightness in tone shows that he is playfully jesting the nature of mankind. His accusation of mankind is openly voiced, without the kind of controlled expression of Pope and Johnson:

\title{
Vain human Kind! Fantastick Race!
}


Thy various Follies, who can trace?

Self-love, Ambition, Envy, Pride,

Their Empire in our Hearts divide:

Give others Riches, Power, and Station,

'Tis all on me an Usurpation. (line 39-44)

The modifiers he gives to mankind is "Vain" and "Fantastick", the latter of which apparently means "foolish". The "various Follies", "Self-love, Ambition, Envy, Pride", are inherently human character traits. Our hearts and mind are conquered by these vices. Swift uses "me" to refer to himself, which suggests that he is also the victim of these "Follies", without the high moral and spiritual posture that Pope and Johnson assume in their poems. "I" cannot bear to give away "Riches, Power, and Station" to others. Swift is jesting and even a little self-deprecating. We remember that these "Follies" are but the "Ambition" mentioned by Pope and Johnson. "Self-love" especially is central to Swift's ideas of human nature:

In Pope, I cannot read a Line,

But with a Sigh, I wish it mine:

When he can in one Couplet fix

More Sense than I can do in Six:

It gives me such a jealous Fit,

I cry, Pox take him, and his Wit. (line 47-52)

He is so jealous of his friend Pope's talent that he wishes he and his wit are all taken away. This echoes the maxim Swift quotes and shows his self-love:

To all my Foes, dear Fortune, send

Thy Gifts, but never to my Friend:

I tamely can endure the first,

But, this with Envy makes me burst. (line 67-70)

This is an extreme example of his self-love. If fortune will send "Gifts", better to "all my Foes" than to "my Friend". "I" can endure the first but I can never endure the second. "I" will burst with "Envy", which comes from the self-love of human nature. Then he goes on to talk about his supposed death and the world is gossiping about him but does not care much. Everybody is minding his own business, except one person who gives him an impartial account.

"Self-love" is central to Swift's ideas of human nature, which is the folly he principally attacks in the entire course of this poem. We can say that "Self-love" is the chief human nature. Everybody is basically self-centered, primarily caring about his own business and interests.

\section{Conclusion}

In conclusion, the poetic styles of Pope, Swift and Johnson in the three poems, are grand, milder, and colloquial. Pope and Johnson are didactic while Swift is jesting. And their different styles indicate that their views on human nature also vary. The principal traits of human nature concerned in their poems are self-love, reason, and vanity. Self-love and vanity are shared by the three. Self-love is central in Pope's conception of human nature, while he uses reason to counterbalance selflove. For Johnson, however, what is intrinsic to human nature is vanity. It is vanity that leads people to each anxious toil and each eager strife, thus resulting in a protracted life of fruitless toil, vain hope and disappointment. Like Pope, he also mentioned "reason" several times in this poem, which indicates his emphasis of reason as the resolution to all unhappiness in human life. Yet, Johnson lost all the hopefulness as evinced in Pope's poem. His view of human life and of human nature is quite gloomy. As for Swift, he does not even mention reason in his poem. Perhaps he does not think reason is intrinsic in human nature or man is even not capable of reason. We can get proof from his humorous description of the Houyhnhnms and the Yahoos in his novel Gulliver's Travels. It is the Houyhnhnms who are capable of reason while the Yahoos, on the other hand, are quite whimsical in their actions. "Gulliver (a symbol here for Man) is set between the Houyhnhnms (naturally reasonable animals) and the Yahoos (Man-denegerated-into-beasts without reason). It is soon all too obvious that Gulliver more nearly resembles the Yahoos than he does the Houyhnhnms." ( Redinger, 1946, p. 224) Therefore, Jonathan Swift even has no faith in human reason. This also manifests "the satirist's traditional low view of human nature" (Waingrow, 1965, p. 513).

Thus, from Alexander Pope to Samuel Johnson and then down to Jonathan Swift, their respective poetic styles drop in formality and start to be increasingly less serious. Their respective view of human nature, accordingly, becomes increasingly hopeless and bleak. From their writings, we can infer that ego-centrism is their shared understanding of human nature. Yet, Jonathan Swift, among the three, possesses the bleakest view of human nature. 


\section{References}

Aden, J. (1961). Rasselas and The Vanity of Human Wishes. Criticism, 3(4), 295-303.

Bate, W. J. (1977), Samuel Johnson. New York: Harcourt Brace Jovanovich.

Branciforte, J. (2019). Pope's Perversity: Tastemaking in Liberal Culture. Modern Language Quarterly, 80(3), $261-286$.

Chapin, C. (1984). Johnson's Intentions in The Vanity of Human Wishes. Eighteenth-Century Studies, 18(1), $72-75$.

Davis, H. (1940). The Poetry of Jonathan Swift. College English, 2(2), 102-115.

Johnson, S. (1977). The Vanity of Human Wishes. In F., Brady \& W. K., Wimsatt. (Ed.). Samuel Johnson: Selected Poetry and Prose (pp. 57-67). Berkeley: University of California Press.

Pope, A. ( 2008). An Essay on Man. In P., Rogers (Ed.). Alexander Pope: The Major Works (pp. 270-308). Oxford: Oxford University Press.

Redinger, R. (1946). Jonathan Swift, the Disenchanter. The American Scholar, 15(2), 221-226.

Swift, J. (2015). Verses on the Death of Dr. Swift. In D., Fairer \& C., Gerrard (Ed.). Eighteen-Century Poetry: An Annotated Anthology ( ${ }^{\text {rd }}$ ed., pp. 100-113). New Jersey: Wiley Blackwell.

Tobin, J. (1945). Alexander Pope and Classical Tradition. Bulletin of the Polish Institute of Arts and Sciences in America, 3(2), 343-354.

Voltaire. (2003). Philosophical Letters. New York: Courier Dover Publications.

Waingrow, M. (1965). Verses on the Death of Dr. Swift. Studies in English Literature, 1500-1900, 5(3), 513-518.

Weinbrot, H. D. (1997), Johnson's Poetry. In C., Greg (Ed.). Cambridge Companion to Samuel Johnson. Cambridge: Cambridge University Press. 